\title{
Indotestudo travancorica (Boulenger 1907) - Travancore Tortoise
}

\author{
V. DeEPaK ${ }^{1}$, Madhuri RAMESh ${ }^{2}$, S. Bhupathy ${ }^{3}$, ANd Karthikeyan VASUdevan ${ }^{1}$ \\ ${ }^{1}$ Wildlife Institute of India, P.O. Box 18, Dehradun 248001 India[deepaksalea@gmail.com, karthik@wii.gov.in]; \\ ${ }^{2}$ Ashoka Trust for Research in Ecology and the Environment, Royal Enclave, Sriramapura, \\ Jakkur Post, Bangalore 560064, India [madhurir@hotmail.com]; \\ ${ }^{3}$ Sálim Ali Centre for Ornithology and Natural History, Anaikatty P.O., \\ Coimbatore641108 India [bhupathy.s@gmail.com]
}

Summary. - The Travancore Tortoise, Indotestudo travancorica (Family Testudinidae) is a medium-sized tortoise (straight carapace length $[S C L]$ up to $331 \mathrm{~mm}$ ) endemic to the mountain ranges of the Western Ghats in southwestern India. The taxonomy of the genus Indotestudo has recently been revised, and $I$. travancorica is considered a distinct species. It is found in semi-evergreen, evergreen, moist deciduous, and bamboo forests, as well as in rubber and teak plantations, occurring mostly near streams and marshes, with a home range of 5.2-34 ha. Travancore Tortoises are omnivorous; their diet encompasses grasses to mollusks and they occasionally scavenge on dead animals. They breed from November to March in captivity, have a clutch size of 1-5 eggs, and hatchlings measure $55-60 \mathrm{~mm} \mathrm{SCL}$. The major threats to this species are hunting and habitat loss. Conservation measures should focus on protection, identification of crucial tortoise habitats, and increasing awareness among local communities.

Distribution. - India. Endemic to the Western Ghats, across the states of Kerala, Karnataka, and Tamil Nadu of southwestern India.

Synonymy. - Testudo travancorica Boulenger 1907, Testudo (Indotestudo) travancorica, Geochelone travancorica, Geochelone (Indotestudo) travancorica, Indotestudo travancorica.

SubSPECIES. - None recognized.

Status. - IUCN 2011 Red List: Vulnerable (VU A1cd) (assessed 2000); CITES: Appendix II, as Testudinidae spp.; Indian Wildlife (Protection) Act (1972): Schedule IV.

Taxonomy. - Indotestudo travancorica was first described by Boulenger (1907) as Testudo travancorica based on specimens collected by Ferguson, who believed it to be common in the Travancore hills of Kerala, southwestern
India. Boulenger noted that it bore resemblance to both Testudo elongata, from the northern and eastern parts of the Indian subcontinent, and T. forsteni [sic] from Celebes (now Sulawesi, Indonesia) and the neighboring Gilolo Is-

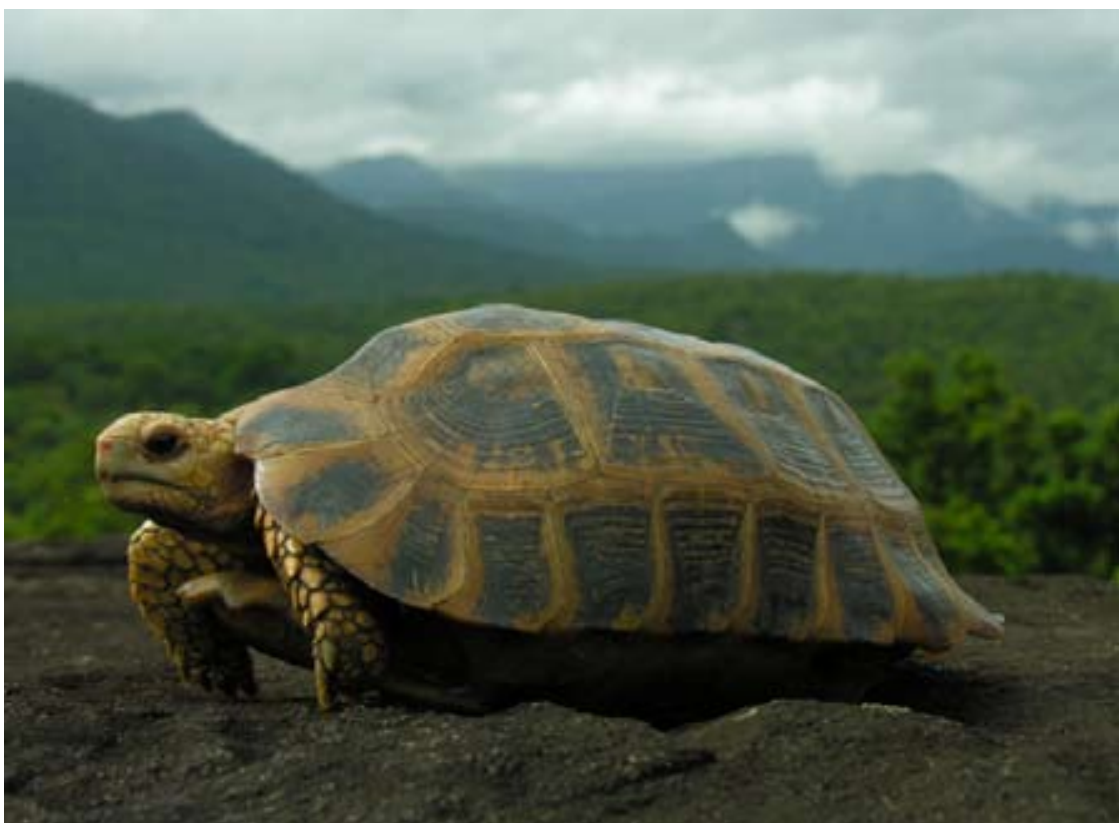

Figure 1. Female Indotestudo travancorica from the Anamalai hills, southern Western Ghats, India. Photo by V. Deepak. 


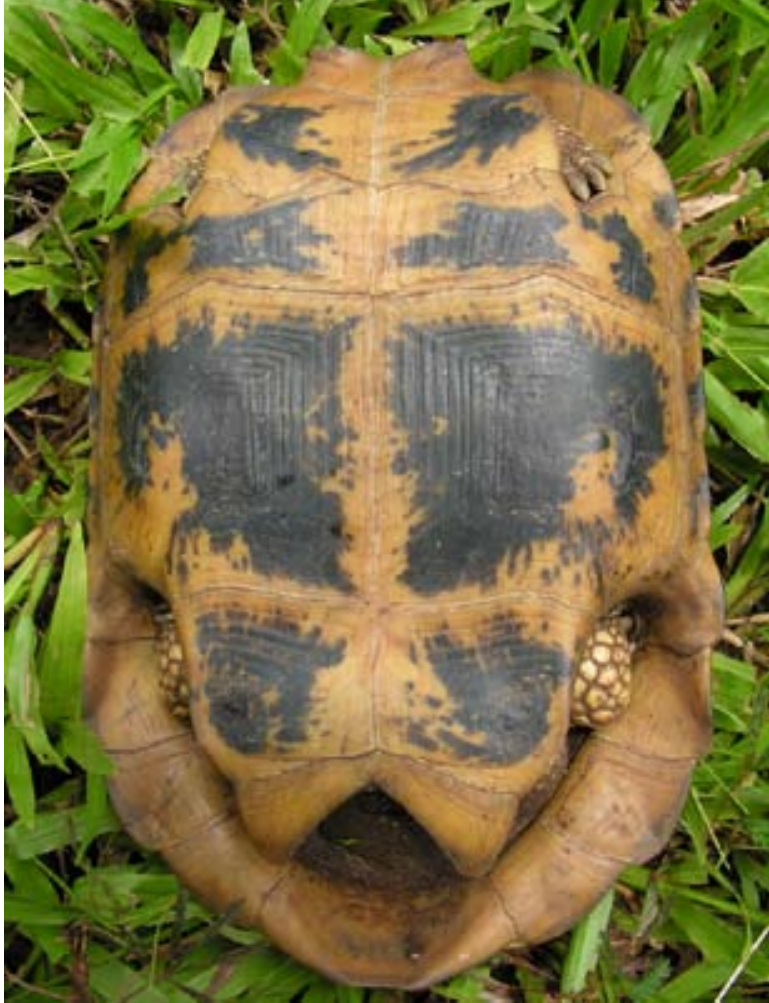

Figure 2. Ventral view of an adult female Indotestudo travancorica . Photo by V. Deepak.

land (now Halmahera, Maluku, Indonesia). Smith (1931) also considered T. travancorica as very closely allied to $T$. elongata.Lindholm (1929) first recognized T. elongata as a distinct species and assigned it to the subgenus Indotestudo (under Testudo) (Fritz and Havas 2007). While Lindholm did not mention the placement of the other two valid names, Williams (1952) included travancorica and forstenii in this subgenus. Subsequently, Williams (in Loveridge and Williams 1957) partitioned the all-encompassing tortoise genus Testudo, by placing three tortoise species in the subgenus Indotestudo, which in turn was placed under the genus Geochelone. Bour (1980) elevated Indotestudo to a

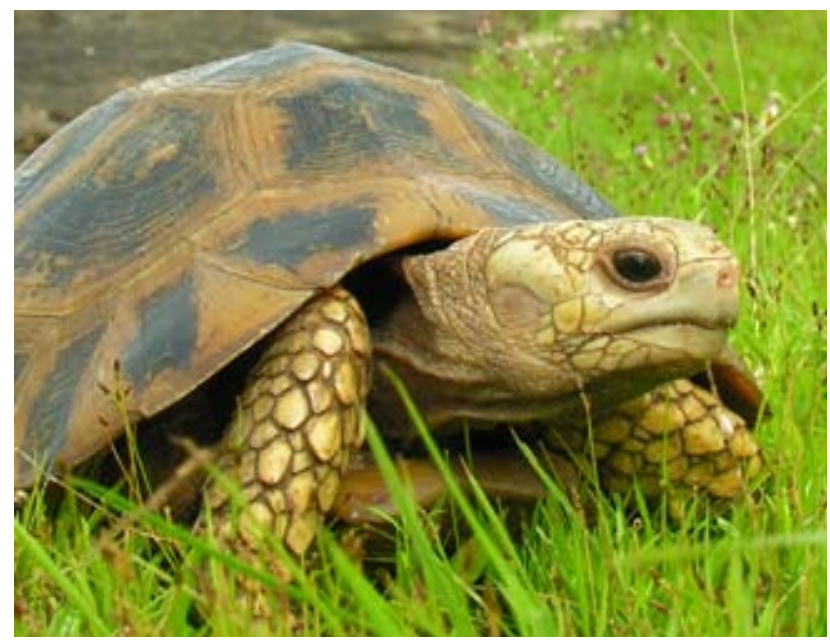

Figure 3. Close-up of the head of an adult male Indotestudo travancorica. Photo by V. Deepak. distinct genus; this was supported by cladistic analyses by Crumly $(1982,1984)$.

Pritchard (1979) suspected that tortoises from India could have been introduced into Indonesia, giving rise to disjunctive populations. When Hoogmoed and Crumly (1984) examined specimens of the three species of Indotestudo, they were unable to distinguish I. forstenii from $I$. travancorica. Therefore, I.travancorica was synonymized with I. forstenii, with the latter name taking priority. Since then, the species name I. forstenii has been associated with many reports of I. travancorica (e.g., Frazier 1989; Das 1991, 1995; Sharath 1990; Bhupathy and Choudhury 1995; Radhakrishnan 1998). After examining specimens of Indotestudo from different regions, Pritchard (2000) suggested that I. travancorica be resurrected as a separate species because it was morphologically distinct from $I$. forstenii and I. elongata. Phylogenetic evidence supported the recognition of three distinct species, and also revealed that I.travancorica was more closely related to I. elongata than to I. forstenii (Iverson et al. 2001; Le at al. 2006).

Description. - Adult I. travancorica have elongated shells, usually flattened at the vertebral region with margins that may be reverted and mildly serrated at the anterior and posterior ends. The carapace and plastron are brown to chocolate brown and may have blackish blotches; blotches on the vertebrals are usually surrounded by a central brown blotch that may fade into the marginals (Figs. 1-2). The head is cream or yellowish-brown with pinkish-red coloration around the orbital skin and nares. The iris is dark brown; the upper mandible is slightly hooked and tricuspid (Fig. 3). Large, uneven, imbricate scales cover the anterior part of the forelimbs. The tail ends in a claw-like spur (Boulenger 1907; Das 1991; Pritchard 2000). Absence of the nuchal (cervical) scute (or if present, wedge-shaped), and the interhumeral seam that is 1-1.4 times the length of the interpectoral seam, differentiate it from its congeners I. elongata and I.forstenii (Pritchard 2000).

A sexually dimorphic species, the abdominal region of the plastron is concave in males and flat in females, while the tail claw is longer and hooked in males, and small and conical in females (Auffenberg 1964b; Vijaya 1983; Das

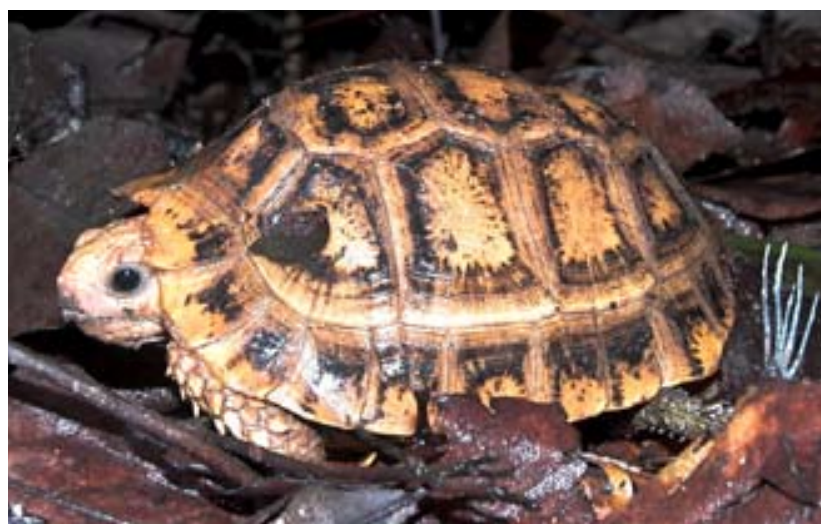

Figure 4. Yearling of Indotestudo travancorica from the Anamalai hills, Western Ghats. Photo by V. Deepak. 


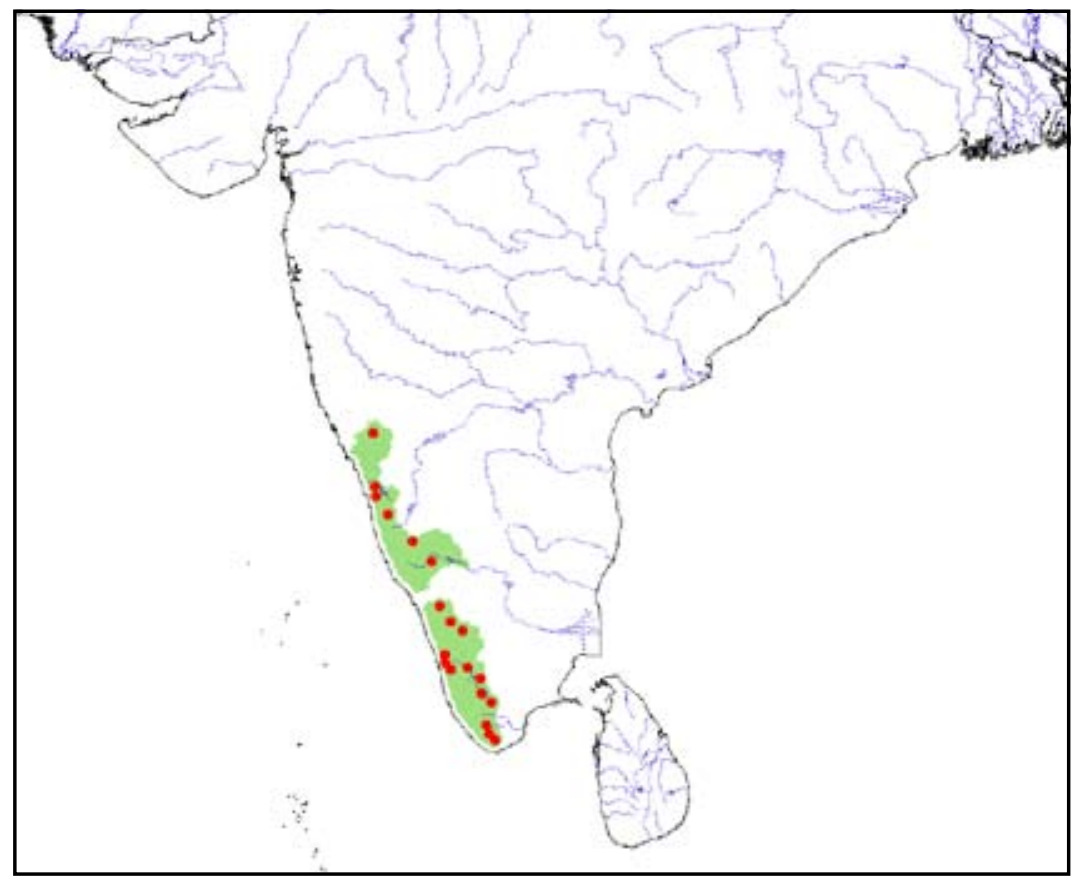

Figure 5. Distribution of Indotestudo travancorica in the Western Ghats of southwestern Peninsular India; the discontinuity in the range is the Palghat Gap. Red dots = museum and literature occurrence records of native populations based on Iverson (1992) plus more recent and authors' data; green shading = projected distribution based on GIS-defined hydrologic unit compartments (HUCs) constructed around verified localities and then adding HUCs that connect known point localities in the same watershed or physiographic region, and similar habitats and elevations as verified HUCs (Buhlmann et al. 2009), and adjusted based on authors' data.

1991). There is no significant size difference between the sexes (Ramesh 2008a). Their straigh carapace length (SCL) ranges from $55-330 \mathrm{~mm}$, and mass from 35-4010 g (Sane and Sane 1988; Appukuttan 1991; Das 1995; Bhupathy and Choudhury 1995; Ramesh 2008a; Vasudevan et al. 2010).

Hatchlings are usually uniformly brown, though in a few, the carapace or plastron may be mottled with darker spots (Fig. 4). The shell is rubbery to touch, especially the plastron. The carapace appears rounded and the anterior and posterior marginals have sharp transparent edges. In newlyhatched tortoises, both the caruncle at the tip of the snout and the umbilical scar on the plastron are discernable (Ramesh, pers. obs.). Age or size at sexual maturity is unknown, but a male having $160 \mathrm{~mm} \mathrm{SCL}$ had a distinctly concave plastron and hooked tail claw (Ramesh 2008b) indicating probable size of male sexual maturity.

Distribution. - Endemic to the Western Ghats of southwestern peninsular India, I. travancorica has been reported from states both south (Kerala, Tamil Nadu) and north (Karnataka) of the Palghat Gap from 100-1000 m above sea level (Boulenger 1907; Smith 1931; Vijaya 1983; Das 1991; Bhupathy and Choudhury 1995; Vasudevan et al. 2010).

Habitat and Ecology. - Travancore Tortoises are found in the evergreen, moist deciduous, bamboo forests, and rubber and teak plantations of the Western Ghats. They frequent marshlands, dry grass openings in the forest, and rocky biotopes close to streams (Vijaya 1983; Bhupathy and Choudhury 1995; Ramesh 2008b; Vasudevan et al. 2010). While inactive, they use leaf litter, ground-level cavities in trees, rocks, fallen logs and occasionally, pangolin burrows for shelter (Vijaya 1983; Bhupathy and Choudhury 1995; Vasudevan et al. 2010).

In a recent study in the Anamalai hills of the Western Ghats (Vasudevan et al. 2010), of 50 individuals recorded, 24 were found near streams and grassy marshes, 15 in forest interiors, and 11 in Lantana camara bush and rocky microhabitats. In 728 tracking days between February 2008 and March 2010, four tortoises with attached radiotransmitters ( 2 males and 2 females) spent about $37 \%$ of the time inactive under leaf litter, $21 \%$ inside Lantana camara scrub, $12 \%$ inside bamboo thicket, $7 \%$ under fallen logs or liana, $6 \%$ in rock cavities and $6 \%$ in ground-level tree hollows, $5 \%$ under grass, $4 \%$ inside pangolin or termite burrows and $2 \%$ in the open. Indotestudo travancorica is crepuscular (Vijaya 1983) and $70 \%$ of 23 tortoises were encountered between 1700 and 1830 hrs (Ramesh 2008b) in the Anamalai hills.

The estimated home range of I. travancorica based on 728 days of radiotracking of four tortoises was 5.2-34 ha and tortoises were active even during midday (Vasudevan et al.2010). The minimum and maximum distances moved in a day were $0.8 \mathrm{~m}$ and $665 \mathrm{~m}$, respectively. Three radiotracked individuals moved $440 \mathrm{~m}$ on average (range $350-586 \mathrm{~m}$ ) in one year.Radiotagged tortoises spent nearly equal proportions being active and inactive during rainy and non-rainy days ( $n=493$ tracking days). However, some individuals buried themselves under leaf litter during the dry season (FebruaryMay) and became inactive. There was no evidence of long-distance movement in this study. However, a report by Ramesh (2004), suggested that a tortoise had traveled about $50 \mathrm{~km}$ in 20 years. 
Tortoises feed on mushrooms, tender bamboo shoots, fallen fruits of Artocarpus spp., Dillenia pentagyna, Ficus virens, and the leaves of herbaceous plants such as Synedrella nodiflora, Desmodium repandum, Senecio scandens, Mimosa pudica, and Veronica buabaumii (Vijaya 1983; Ramesh and Parthasarathy 2006; Vasudevan et al. 2010), apart from animals such as frogs, insects, and millipedes (Das 1991, 1995). Feces collected from 32 tortoises contained at least one identifiable diet item: $91 \%$ had grass/bamboo blades, $94 \%$ other plant matter (leaves and stems), 75\% insect remains, 63\% sand, 38\% seeds (Grewia tilaefolia and Dillenia pentagyna), 22\% vertebrate remains (identified as skink scale, mammal hair, and vertebral bone), $19 \%$ mollusks, $9 \%$ scorpion and crab remains, and $3 \%$ millipedes. They also scavenged on carcasses of mammals such as sambar, Cervus unicolor (Vasudevan et al. 2010).

Travancore Tortoises are known to produce chorus calls at night in captivity; the purpose of the call is unknown (Campbell and Evans, 1972). The vocalizations are probably produced by a posteriodorsal movement of the mandible against the alveolar surface of the upper jaw (Auffenberg's observations in Campbell and Evans, 1972). The calls of tortoises belonging to genus Indotestudo sound like whimpers or bellows and are highly stereotyped for each individual (Galeotti et al. 2005).

Courtship consists of the following stages: 1) sex recognition by olfaction, 2) immobilization of the female by shell-ramming, and 3) mounting and copulation (Auffenberg 1964b). Male combat, consisting of shell-ramming and biting, also occurs (Das 1991; Ramesh 2008a). In adult male $I$. travancorica, the pink coloration around the eyes and nares intensifies during the breeding season, which is from November to January (Auffenberg 1964a). But there are reports of breeding in other months of the year; a gravid free-ranging female was found in October (Moll 1989) and in February-March, in captivity (Das 1991).

Nesting has not been observed in situ. In captivity, the species excavated small chambers near the roots of trees or shrubs for egg-laying, and the entire process took about 50 minutes. Eggs were 47 x $38 \mathrm{~mm}$ and had a mass of 41 $\mathrm{g}$ (Ramesh 2007). In captivity, clutch size varied from 1-5 eggs but was often 3 (Vijaya 1983; Sane and Sane 1988; Das 1991, Ramesh 2007); eggs have also been found on the floor of the enclosure (Sane and Sane 1988) or in leaf litter (Das 1991), likely due to a lack of suitable nesting substrates. The incubation period varied from 141-149 days in captivity and a hatchling measured $55 \mathrm{~mm}$ (SCL) and had a mass of $35 \mathrm{~g}$ (Sane and Sane 1988; Das 1995).

Indotestudo travancorica is occasionally consumed or gnawed upon by large carnivores. A large (280 mm SCL), intact shell of the species (carapace and plastron) from the Parambikulam Wildlife Sanctuary, Kerala, had a deep puncture on a costal and scratch marks on the scutes. Similarly, another live tortoise (172 $\mathrm{mm} \mathrm{SCL}$ ) had extensive scratch marks and was missing a few marginals; this was probably caused by some large carnivore, such as tiger (Panthera tigris), leopard (P.pardus), or dhole wild dog (Cuon alpinus) found in the area.

Population Status. - Indotestudo travancorica was historically reported to be a common species in the forests of the Western Ghats (Boulenger 1907; Henderson 1912; Vijaya 1982) but no current population estimates are available. Encounters of the species during active searches in forests ranged from $6.7 \mathrm{hrs} /$ tortoise in Parambikulam Wildlife Sanctuary (for 20 man-hours) to $8.0 \mathrm{hrs} /$ tortoise in Indira Gandhi and Peechi-Vazhani Wildlife Sanctuaries (for 16 man-hours each) (Bhupathy and Choudhury 1995). The species might be more abundant in relatively undisturbed habitats. For instance, in a survey conducted in 2002-03, 57 tortoises were captured with a mean search effort of 3.4 hrs/tortoise (Ramesh 2008a). Intensive sampling in a large forested landscape carried out during 2006-08 in the same area yielded one tortoise in $17.5 \mathrm{hrs}$ in monsoon (for 508 man-hours), and one in 22.3 hours in summer, winter and post-monsoon (for 401 man-hours), suggesting poor detection of the species by the observers or sparse distribution, or both (V. Deepak, unpubl. data).

Threats to Survival. - Across most of its range, the species is hunted and consumed. Tribes of the Western Ghats such as the Kadar, Malai Pandaram, Kani, Malasar, and Malaimalasar hunt these tortoises using dogs or by following their tracks (Vijaya 1983; Frazier 1989; Moll 1989; Choudhury and Bhupathy 1993; Vasudevan et al. 2010). Sometimes, tortoises are also reared as pets till they attain a size suitable for consumption. Kani tribals also use charred shell mixed with oil as a cure for external injuries and skin rashes (Bhupathy and Choudhury 1995). So far, this species has not been reported in regional trade (Choudhury and Bhupathy 1993). However, subsistence hunting of the species could reduce their populations (Vijaya 1983; Frazier 1989; Moll 1989; Bhupathy and Choudhury 1995).

Habitat alteration and fragmentation of forest due to hydroelectric reservoirs is known from almost all areas where the tortoise occurs (Bhupathy and Choudhury 1995). There are 24 operational and 12 proposed hydroelectric projects in the state of Kerala alone, which would severely impact the biodiversity of this region (Sreekumar and Balakrishnan 1998; Nikhil Raj et al. 2009). These projects also bring in settlers, who pose a threat to the species since they might intensify habitat disturbance and hunting.

Conservation Measures Taken. - Indotestudo travancorica has been listed as Vulnerable on the IUCN Red List since 2000 (www.iucnredlist.org). It is included in Appendix II of CITES under Testudinidae spp. In India, it is protected under Schedule IV of the Indian Wildlife (Protection) Act (1972).

This species has been reported from 12 Wildlife Sanctuaries, three Tiger Reserves, one National Park and seven Reserved Forests in the Western Ghats (Bhupathy and Choudhury 1995). The Western Ghats is a global biodiversity hotspot (Mittermeier et al. 2005) and the conservation of biological diversity has been a priority for India. As a result, 
53 Protected Areas (PA) have been gazetted covering 17\% of the entire biogeographic region; India's PA covers $4.9 \%$ of the total land area. The high proportion of PA cover for the Western Ghats is a reflection of national-level policies aimed at strengthening protection in regions with high biological diversity and endemism. There are currently 53 protected areas in the Western Ghats Mountains (source: PA network, Wildlife Institute of India) covering an area of $11,222.47 \mathrm{~km}^{2}$ and these PAs are of great significance to Travancore Tortoise populations. However, they ensure protection for only $17 \%$ of the entire biogeographic unit that has potential habitat for the species. The reserves in this province have a mean area of $198 \mathrm{~km}^{2}$ with $43 \%$ of them $<100 \mathrm{~km}^{2}$. These limitations expose several populations to exploitation and insularization of remnant habitats of the species.

Conservation Measures Proposed. - We propose that the current IUCN Red List status of Vulnerable be retained for I. travancorica because it is an endemic species experiencing unabated pressure from subsistence hunting. More significantly, recurrent attempts to establish new hydroelectric projects in this region will result in rapid, extensive, and irreversible habitat loss. Conservation efforts focusing on increasing the PA cover and improving connectivity within the existing PAs will be one of the priorities for the survival of the species. Creating awareness among forest protection staff will help in enhancing protection for the species. Removal of domestic dogs from PAs will also considerably reduce the threat of exploitation of the species. Crucial habitats such as the swamps in woodland openings (locally known as 'vayal') also require area-specific protection and management since vayals provide an important foraging area for tortoises during the dry season and probably serve as refuge during forest ground fires.

Captive Husbandry. - The Centre for Herpetology, Madras Crocodile Bank Trust has the only captive breeding group of this species in the country. At present, the population consists of 4 males, 12 females, 5 juveniles and 5 hatchlings (MCBT Taxon report 2011, Nikhil Whitaker, pers comm.). Some observations on this captive group have been published over the years (Vijaya 1983; Das 1991, Ramesh 2007).

Current Research. - It is expected that the recently completed research project on the ecology of I.travancorica in the Anamalai hills by Wildlife Institute of India will provide much-needed information on the ecology of the species from the wild. Ongoing monitoring of the captive tortoises at the Centre for Herpetology, Madras Crocodile Bank Trust would provide further insights on husbandry and developmental biology of the species.

Acknowledgments. - We thank the Wildlife Institute of India, Centre for Herpetology, Madras Crocodile Bank Trust, U.S Fish and Wildlife Service, Sálim Ali Centre for Ornithology and Natural History, and the Forest Departments of Kerala, Karnataka and Tamil Nadu for their generous support. VD thanks the Doris Norden Herpetological Fund and Madras Crocodile Bank Trust for financial support. We are grateful to the indigenous people of the Western Ghats for assisting us in the field during our studies.

\section{LITERATURE CITED}

APPUKUTTAN, K.S. 1991.A survey report of cane turtle and Travancore tortoise. Kerala: Kerala Forest Department, 21 pp.

AufFENBERG, W. 1964a. A first record of breeding colour changes in a tortoise. Journal of the Bombay Natural History Society 61:191-192.

AUFFENBERG, W. 1964b. Notes on the courtship of the land tortoise Geochelone travancorica (Boulenger). Journal of the Bombay Natural History Society 61:247-253.

AufFEnBERG, W. 1977. Display behaviour in tortoises. American Zoologist 17(1):241-250.

Bhupathy, S. AND Choudhury, B.C. 1995. Status, distribution and conservation of the Travancore tortoise, Indotestudo forstenii in Western Ghats. Journal of the Bombay Natural History Society 92:16-21.

BOULENGER, G.A. 1907. A new tortoise from Travancore. Journal of the Bombay Natural History Society 17:560-564.

Bour, R. 1980. Essai sur la taxinomie des Testudinidae actuels (Reptilia: Chelonii). Bulletin of the Museum of Natural History Paris 4:541-546.

Buhlmann, K.A., Akre, T.S.B., Iverson, J.B., Karapatakis, D., MitTERMEIER, R.A., GeOrges, A., Rhodin, A.G.J., vAN DiJK, P.P., AND GiBbons, J.W. 2009. A global analysis of tortoise and freshwater turtle distributions with identification of priority conservation areas. Chelonian Conservation and Biology 8(2):116-149.

Campbell, H.W. and Evans, W.E. 1972. Observations on the vocal behavior of chelonians. Herpetologica 28(3):277-280.

Choudhury, B.C. And Bhupathy, S. 1993. Turtle Trade in India: A study of Tortoises and Freshwater Turtles. WWF - India, TRAFFIC - India, New Delhi, 50 pp.

CRumly, C.R. 1982. A cladistic analysis of Geochelone using cranial osteology. Journal of Herpetology 16: 215-234.

CRUMLY, C.R. 1984. A hypothesis for the relationship of land tortoise genera (family Testudinidae). Studia Geologica Salamanticensia, Vol. Especial 1. Studia Paleochelonologica 1: 115-124.

DAs, I. 1991. Colour guide to the turtles and tortoises of the Indian subontinent. Avon, United Kingdom: R\&A Publishing Ltd., 133 pp.

DAs, I. 1995. Turtles and tortoises of India. World Wide Fund for Nature - India. Bombay: Oxford University Press, 176 pp.

FrazIER, J. 1989. Chelonians of the Western Ghats. Hamadryad 14(2): 4-7.

Fritz, U. AND HaVas, P. 2007. Checklist of chelonians of the world. Vertebrate Zoology 57(2):149-368.

Galeotti, P., SAcchi, R., Fasola, M., and Ballasina, D. 2005. Do mounting vocalisations in tortoises have a communication function? A comparative analysis. Herpetological Journal 15:16-71.

Groombridge, B., Moll, E.O., AND ViJAYA. J. 1983. Rediscovery of a rare Indian turtle. Oryx 17:130-134.

HENDERSON, J.R. 1912. Preliminary note on a new tortoise from south India. Records of the Indian Museum 7:217-218.

Hoogmoed, M.S. AND CRUMLY, C.R., 1984. Land tortoise types in the Rijksmuseum van Natuurlijke Histoire with comments on nomenclature and systematics (Reptilia: Testudines: Testudinidae). Zoologische Mededelingen Rijksmuseum van Natuurlijke Histoire Leiden 58:241-259.

IUCN (International Union for Conservation of Nature). 2008. Indotestudo travancorica. In: IUCN Red List of threatened Species. www.iucnredlist.org. 
IVERSON,J.B. 1992.ARevised Checklist with Distribution Maps of the Turtles of the World. Richmond, IN: Privately published, $363 \mathrm{pp}$.

Iverson, J.B., SPINKS, P.Q., SHAFFER, H.B., McCord, W.P., AND DAS, I. 2001. Phylogenetic relationships among the Asian tortoises of the genus Indotestudo(Reptilia:Testudines:Testudinidae).Hamadryad 26:272-275.

Jenkins, M.D. 1995. Tortoises and Freshwater Turtles: The trade in Southeast Asia. United Kingdom: TRAFFIC International, 48 pp.

Le, M., RaXworthy, C.J., McCord, W.P., AND Mertz, L. 2006. A molecular phylogeny of tortoises (Testudines: Testudinidae) based on mitochondrial and nuclear genes. Molecular Phylogenetics and Evolution 40:517-531.

LindHOLM, W.A. 1929. Revediertes Verzeichins der Gattung der rezenten Schildkröten nebst Notizen zur Nomenklatureingen Arten. Zoologischer Anzeiger 81:275-295.

LOVERIDGE, A. AND WILLIAMs, E.E. 1957. Revision of the African tortoises and turtles of the suborderCryptodira.Bulletin of the Museum of Comparative Zoology Harvard 115:163-557.

Mittermeier, R.A., Gill, P.R., Hoffman, M., Pilgrim, J., Brooks, T., Mittermeier, C.G., Lamoreux, J., and da Fonseca, G.A.B. 2005. Hotspots Revisited: Earth's Biologically Richest and Most Endangered Terrestrial Ecoregions. Conservation International and Agrupacion Sierra Madre, Monterrey, Mexico: CEMEX Publications.

Moll, E.O. 1989. Indotestudo forstenii, Travancore tortoise. In: Swingland, I.R. and Klemens, M.W. (Eds). The Conservation Biology of Tortoises. Occasional Papers, IUCN/SSC No. 5, pp. 119-120.

Nikhil RaJ, P.P., Ranini, J., Dhanya, R., And AzeEz, P.A. 2009. Energy scenario and environmental implications: an overview of Kerala, India. Journal of Environment and Energy 1:60-76.

Pritchard, P.C.H. 1979. Encyclopedia of Turtles. Neptune, New Jersey: T.F.H. Publications, 895 pp.

PRITCHARD,P.C.H.2000.Indotestudo travancorica ... a valid species of tortoise? Reptile and Amphibian Hobbyist. February:18-28.

RADHAKRISHAN, C. 1998. Additional record of the Travancore tortoise, Indotestudo forstenii (Schlegel \& Muller) (Testudinidae: Reptilia) in Kerala. Cobra 34:19-20.

RAMESH, M. 2004. Long distance dispersal by a Travancore tortoise, Indotestudo travancorica. Hamadryad 28:105.

Ramesh, M. AND Parthasarathy, N. 2006. A note on the diet of Travancore tortoise Indotestudo travancorica. Journal of the Bombay Natural History Society 103:106.

RAMESH, M. 2007. Hole-nesting in captive Indotestudo travancorica. Journal of the Bombay Natural History Society 104:101.

RAMESH, M. 2008a. Relative abundance and morphometrics of the
Travancore tortoise, Indotestudo travancorica, in the Indira Gandhi Wildlife Sanctuary, southern Western Ghats, India. Chelonian Conservation and Biology 7:108-113.

RAMESH, M. 2008 b. Preliminary survey of Indotestudo travancorica (Testudinidae) at the Indira Gandhi Wildlife Sanctuary, southern India. Hamadryad 33:118-120.

Rodgers, W.A. and Panwar H.S. 1988. Planning a Wildlife Protected Area Network in India Volume I - The Report. Wildlife Institute of India, Dehra Dun.

SANE, L.S. AND SANE, R.S. 1988. Some observations on growth of the Travancore tortoise (Geochelone travancorica). Journal of the Bombay Natural History Society 86:109.

Sharath, B.K. 1990. The land tortoises along the Western Ghats of Karnataka - an excellent indicator. Journal of the Ecological Society 3:41-44.

SмIтн, M.A. 1931. The fauna of British India, including Ceylon and Burma: Reptilia and Amphibia. Volume I. Loricata, Testudines. London: Taylor and Francis, 185 pp.

SREeKUMAR, P.G. AND BALAKRISHNAN, M. 1998. A study of the animal diversity in the proposed Adirapally hydro-electric project area in Kerala. International Journal of Ecology and Environmental Science 24:393-410.

Vasudevan, K., Pandav, B., and DeepaK. V. 2010. Ecology of two endemic turtles in the Western Ghats. Final Technical Report, Wildlife Institute of India, $74 \mathrm{pp}$.

VIJAYA, J. 1982. Rediscovery of the forest cane turtle Heosemys (Geoemyda) silvatica (Reptilia, Testudinata, Emydidae) from Chalakudy forest in Kerala. Journal of Bombay Natural History Society 79:676-677.

VIJAYA, J. 1983. The Travancore tortoise, Geochelone travancorica. Hamadryad 8:11-13.

WiLliams, E.E. 1952. A new fossil tortoise from Mona Island, West Indies, and a tentative arrangement of the tortoises of the world. Bulletin of the American Museum of Natural History 99:541-560.

\section{Citation Format for this Account:}

DeepaK, V., Ramesh, M., Bhupathy, S., and Vasudevan, K. 2011. Indotestudo travancorica (Boulenger 1907) - Travancore Tortoise. In: Rhodin, A.G.J., Pritchard, P.C.H., van Dijk, P.P., Saumure, R.A., Buhlmann, K.A., Iverson, J.B., and Mittermeier, R.A. (Eds.). Conservation Biology of Freshwater Turtles and Tortoises: A Compilation Project of the IUCN/SSC Tortoise and Freshwater Turtle Specialist Group. Chelonian Research Monographs No. 5, pp. 054.1-054.6, doi:10.3854/crm.5.054. travancorica.v1.2011, http://www.iucn-tftsg.org/cbftt/. 